\title{
Effect of Dietary Anthocyanin-Extracted Residue on Meat Oxidation and Fatty Acid Profile of Male Dairy Cattle
}

\author{
Ronnachai Prommachart ${ }^{1}{ }^{\mathbb{D}}$, Anusorn Cherdthong ${ }^{1} \mathbb{D}$, Chainarong Navanukraw ${ }^{1}$, Paweena Pongdontri ${ }^{2}$, \\ Wichit Taron ${ }^{2}$, Juntanee Uriyapongson ${ }^{3}$ and Suthipong Uriyapongson ${ }^{1, *}$ \\ 1 Department of Animal Science, Faculty of Agriculture, Khon Kaen University, Khon Kaen 40002, Thailand; \\ prommachart1@gmail.com (R.P.); anusornc@kku.ac.th (A.C.); chanav@kku.ac.th (C.N.) \\ 2 Department of Biochemistry, Faculty of Science, Khon Kaen University, Khon Kaen 40002, Thailand; \\ paweena@kku.ac.th (P.P.); Wichit_t@kkumail.com (W.T.) \\ 3 Department of Food Technology, Faculty of Technology, Khon Kaen University, Khon Kaen 40002, Thailand; \\ juntanee@kku.ac.th \\ * Correspondence: suthipng@kku.ac.th; Tel.: +66-831-417-358
}

\section{check for}

updates

Citation: Prommachart, R.;

Cherdthong, A.; Navanukraw, C.;

Pongdontri, P.; Taron, W.;

Uriyapongson, J.; Uriyapongson, S.

Effect of Dietary Anthocyanin

-Extracted Residue on Meat Oxidation and Fatty Acid Profile of Male Dairy

Cattle. Animals 2021, 11, 322.

https://doi.org/10.3390/ani11020322

Academic Editors

Federica Bellagamba and

Raffaella Rossi

Received: 4 January 2021

Accepted: 25 January 2021

Published: 28 January 2021

Publisher's Note: MDPI stays neutral with regard to jurisdictional claims in published maps and institutional affiliations.

Copyright: (c) 2021 by the authors Licensee MDPI, Basel, Switzerland. This article is an open access article distributed under the terms and conditions of the Creative Commons Attribution (CC BY) license (https:// creativecommons.org/licenses/by/ $4.0 /)$.
Simple Summary: Residue produced by the extraction of anthocyanin from black rice and purple corn contains anthocyanins and phenolic acids. Several researchers have found that anthocyanins and phenolic acids have antioxidant functions in animals. Moreover, black rice and purple extracts have been reported as antioxidants in meat and meat products. However, the effects of anthocyaninextracted residue (AER) from black rice and purple corn as animal feed on the fatty acid profile and oxidation of meat are still unknown. Therefore, the aim of this study was to investigate the effects of the inclusion level of AER in cattle diet on meat fatty acids' profile and meat oxidation during storage. Our results showed that AER in cattle diet reduced the oxidation of lipid and protein of meat and had better red color stability during storage. In addition, it could improve concentration of n-3 polyunsaturated fatty acids (PUFA). In summary, AER in the feed of cattle could reduce meat oxidation leading to the extension of the shelf life of meat. Moreover, meat from cattle-fed AER had higher n-3 PUFA, which indicates healthier meat for consumers.

Abstract: This research aimed to evaluate the effects of anthocyanin-extracted residue (AER) in the diet of cattle on meat oxidation during storage and on the fatty acid profiles of the meat. Sixteen male dairy cattle (average body weight $160 \pm 10.6 \mathrm{~kg}$ ) were allotted to feed in a completely randomized design (CRD) with four levels of AER supplementation, 0, 20, 40, and $60 \mathrm{~g} / \mathrm{kg}$ dry matter (DM) in the total mixed ration (TMR). These TMR diets were fed ad libitum to the cattle throughout the trial. At the end of the feeding trial (125 days), all cattle were slaughtered and meat samples from the Longissimus dorsi (LD) muscle were collected to assess meat oxidation and fatty acid profile. The antioxidant effect of AER on meat oxidation was investigated during 14 days of storage based on color, myoglobin redox forms, lipid, and protein oxidation. The results showed meat from cattle fed AER had better color stability, lower oxidation of lipid, protein and myoglobin than did meat from cattle fed the control diet $(0 \mathrm{~g} / \mathrm{kg}$ AER). Furthermore, fatty acid profiles were affected by AER supplementation with an increase in the concentration of n-3 polyunsaturated fatty acids (PUFA). These results support the inclusion of AER supplementation as a natural antioxidant in cattle to reduce meat oxidation and increase PUFA in meat.

Keywords: anthocyanin extracted residue; beef; meat oxidation; shelf life; fatty acid profile

\section{Introduction}

Beef consumption in Thailand was about 122,000 tonnes [1] and beef production was about 133,000 tonnes in 2019 [2]. However, there are substantial levels of imports of high-quality frozen beef from Australia and New Zealand [3]. Holstein Friesian (Bos taurus) cattle are the most common breed of dairy cattle in Thailand. Dairy farms depend on 
female cows to produce milk, whereas male calves are a surplus to requirements and farmers are raised for beef production. Advantages of Holstein males for beef fattening are better weights and higher growth performance and meat tenderness compared to Bos indicus cattle [4]. Holstein beef would potentially be able to replace imported beef. However, humidity, high levels of solar irradiance, and air temperature of tropical locations negatively affect dairy cattle, causing heat stress in Bos taurus cattle [5]. This generates free radicals resulting in oxidative stress [6]. In particular, lipid peroxidation and protein oxidation is generated by oxidative stress, leading to non-microbiological factors related to meat deterioration and low quality [7]. Lipid peroxidation has a negative impact on muscle pigments, which changes in appearance from red to brown influencing the perceived acceptability of the meat among consumers [8]. The process of lipid peroxidation produces off odors, and flavors, cause loss of water-holding capacity and decrease shelf-life [9]. In addition, several reports showed that lipid peroxidation created toxic compounds implicated in a number of human pathologies, including aging processes, atherosclerosis, inflammation and cancer [10]. Moreover, meat from Holstein cattle was sensitive to lipid peroxidation and color deterioration, impacting meat quality [11].

The natural level of resistance to oxidation depends on the balance between free radical production and antioxidant defenses present in meat or muscle tissue, which is the most important internal factor together with fatty acid profiles [12]. The primary strategy to delay or reduce lipid peroxidation in the meat industry is the addition of antioxidants to meat and meat products. The antioxidant substrates are contained in phenolic structures that can be of synthetic or natural origin. However, there are concerns about the potential of synthetic antioxidants to cause toxicological effects [13]. One strategy to reduce meat oxidation relies on the addition of antioxidants from natural supplements to the animal diets. Several researchers reported that feeding with natural antioxidants improve meat oxidation in chickens [14], pigs [15], lamb [16], goats [17] and cattle [18].

Feeding agro-industrial residues to livestock not only reduces environmental problems caused by residue accumulation and decreases the carbon footprints of animal production [19] but also improves the shelf-life stability and quality of meat $[16,20]$ due to the presence of bioactive compounds such as phytochemicals and vitamins. Black rice (Oryza sativa L.) and purple corn (Zea mays L.) have been described as novel sources of natural antioxidants. They are rich in anthocyanins and phenolic compounds [21,22], which play a role as antioxidant that their structure can be able to donate electrons to the free radicals with unpaired electrons and reduce agents in the electron-transfer reaction pathway [23]. Antioxidant activity of anthocyanin also increased desaturase enzymes activity for converting monounsaturated fatty acid (MUFA) to polyunsaturated fatty acid (PUFA) or inserting additional unsaturated bonds into already existing PUFA [24]. Several studies reported that black rice extract retarded lipid peroxidation, improved redness of color and increased oxidative stability during storage of ground beef patties [25], steak beef [26], pork patties [27], and Thai fermented sausage [28]. Likewise, studies indicated that dietary intake of plant-rich anthocyanin improved oxidative stress status in animals $[29,30]$ and increased the omega-3 (n-3) and omega-6 (n-6) PUFA proportion in the plasma of humans [31], fish [32], and rats [33].

Although the addition of anthocyanin extracted from black rice has antioxidant functions in meat and meat products, no studies have been undertaken to investigate the effects of dietary intake of anthocyanin on meat oxidation and the fatty acid profiles of cattle. Therefore, the objectives of this study were to evaluate the effect of dietary supplements of anthocyanin-extracted residue (AER) on the fatty acid profiles and meat oxidation in male dairy cattle.

\section{Materials and Methods}

\subsection{Animals, Treatments, and Experimental Design}

This experiment was conducted at the Department of Animal Science, Khon Kaen University, Thailand $\left(16^{\circ} 28^{\prime} 00.3^{\prime \prime} \mathrm{N} 102^{\circ} 48^{\prime} 37.9^{\prime \prime}\right.$ E). Animal care has followed the guidelines 
recommended by the Animal Ethics Committee of Khon Kaen University (U1-04090-2559). Sixteen male Holstein cattle (7-8 months) with an average body weight of $160 \pm 10.6 \mathrm{~kg}$, similar body condition score, obtained from the Muak Lek Dairy Co-operative Ltd., Saraburi, Thailand, were randomly assigned to one of four treatment groups $(n=4)$ according to a completely randomized design (CRD) with varying levels of added AER in the total mixed ration (TMR). The experimental diet groups were labeled T1 (AER $0 \mathrm{~g} / \mathrm{kg}$ in TMR), T2 (AER $20 \mathrm{~g} / \mathrm{kg}$ in TMR), T3 (AER $40 \mathrm{~g} / \mathrm{kg}$ in TMR) and T4 (AER $60 \mathrm{~g} / \mathrm{kg}$ in TMR), respectively. All TMR diets were formulated to provide $12 \%$ crude protein (CP) and $15 \mathrm{MJ} / \mathrm{kg}$ gross energy (GE) to meet the nutrient requirements of growing male dairy cattle according to the National Research Council (NRC) [34]. The ingredients, chemical composition and fatty acid profiles of the experimental diets are shown in Table 1. Dry matter (DM), CP, fat content (measured by ether extract, EE) and ash were determined according the method prescribed by the Association of Official Analytical Chemists (AOAC) [35], whereas neutral detergent fiber (NDF) and acid detergent fiber (ADF) were analyzed using procedures described by Van Soest et al. [36]. The GE levels of feed samples were measured using isoperibol bomb calorimeter AC500 (Leco, St. Joseph, MI, USA).

The bioactive compounds of feed and AER were determined by using samples ( $0.2 \mathrm{~g})$ extracted twice with $10 \mathrm{~mL}$ of acidified methanol dissolved in $1.0 \mathrm{~N} \mathrm{HCl}(85: 15 \mathrm{v} / \mathrm{v})$ and incubated at room temperature for $2 \mathrm{~h}$ with shaking. The extracts were centrifuged at $3000 \mathrm{rpm}$ at $4^{\circ} \mathrm{C}$ for $10 \mathrm{~min}$ and the clear supernatants were collected into a volumetric flask.

Total anthocyanin content was determined by the $\mathrm{pH}$-differential method according to Lee et al. [37]. Briefly, two aliquots $(0.5 \mathrm{~mL})$ of the extracts were diluted $(4.5 \mathrm{~mL})$ with buffer reagents $(0.025 \mathrm{M}$ potassium chloride at $\mathrm{pH} 1.0$ and $0.4 \mathrm{M}$ sodium acetate at $\mathrm{pH} 4.5)$ and incubated in dark for $20 \mathrm{~min}$ at room temperature. The absorbance was measured at 520 and $700 \mathrm{~nm}$ respectively, using a UV1280-Vis Spectrophotometer (Shimadzu, Kyoto, Japan). The results were expressed in mg of cyanidin-3-O-glucoside equivalents per $\mathrm{g}$ dry weight using the equation:

Anthocyanins content (cyaniding-3-glucoside equivalents, mg/L) $=\mathrm{A} \times \mathrm{MW} \times \mathrm{DF} \times 10^{3} /(\varepsilon \times 1)$

where $\mathrm{A}=\mathrm{pH} 1.0\left(\mathrm{~A}_{520} \mathrm{~nm}-\mathrm{A}_{700} \mathrm{~nm}\right)-\mathrm{pH} 4.5\left(\mathrm{~A}_{520} \mathrm{~nm}-\mathrm{A}_{700} \mathrm{~nm}\right)$; MW = molecular weight of cyanidin-3-glucoside $(449.2 \mathrm{~g} / \mathrm{mol}) ; \mathrm{DF}=$ dilution factor; $10^{3}=$ factor for conversion from $\mathrm{g}$ to $\mathrm{mg} ; \varepsilon=$ molar extinction coefficient of cyanidin-3-glucoside $\left(26,900 \mathrm{M}^{-1} \cdot \mathrm{cm}^{-1}\right) ; 1=$ the path length $(\mathrm{cm})$.

The total phenolic content in the feed and AER were determined using the FolinCiocalteu method [38]. Briefly, $200 \mu \mathrm{L}$ of extract was mixed with $600 \mu \mathrm{L}$ Folin-Ciocalteu reagent $(10 \%)$ and stood at room temperature for $5 \mathrm{~min} ; 500 \mu \mathrm{L}$ of $\mathrm{Na}_{2} \mathrm{CO}_{3}(700 \mathrm{mM})$ solution was added to the mixture and incubated at room temperature for $2 \mathrm{~h}$. The absorbance was measured at $765 \mathrm{~nm}$ via the UV1280-Vis Spectrophotometer (Shimadzu, Kyoto, Japan). Gallic acid was used as the calibration standard, and the total phenolic content was expressed as milligrams of gallic acid equivalent (GAE) per gram of dry weight.

Fatty acid analyses were performed by one-step extraction and transmethylation as described by Ruiz-López et al. [39]. Qualitative measurements of fatty acid methyl esters (FAME) content were performed by gas chromatography using Agilent Technologies 7890B Gas Chromatograph (GC) System (Agilent Technologies, Santa Clara, CA, USA) with fused silica capillary columns $(30 \mathrm{~m} \times 0.25 \mathrm{~mm}$, film thickness $0.25 \mu \mathrm{m}$; Stabilwax-MS, Bellefonte, PA, USA).

The cattle were kept indoors housing in individual pens $(2.5 \mathrm{~m} \times 5 \mathrm{~m})$ with concrete floors and were cleaned every morning. Each pen was equipped with a water trough and a feed bunk. Mean temperature, relative humidity, and rainfall are $24^{\circ} \mathrm{C}, 64 \%$, and $36 \mathrm{~mm}$, respectively. All cattle were given their assigned TMR diet ad libitum at 7.00 a.m. and 4.00 p.m. each day. The water was available at all times. The cattle were raised for 30 days with TMR diet (AER $0 \mathrm{~g} / \mathrm{kg}$ in TMR) for adaptation and 125 days for the feeding trial with TMR treatments. At the end of the feeding trail ( $\approx 350 \mathrm{~kg}$ final weight), all cattle were transported to a local commercial abattoir and fasted for $12 \mathrm{~h}$ before slaughter. The cattle were slaughtered according to the conventional procedure that included stunning 
via gunshot and exsanguination. The carcasses were cut according to the Thai cutting style. Meat samples (100 g) were collected from the portion of Longissimus dorsi (LD) muscle, vacuum packed in aluminum foil bags and frozen at $-20{ }^{\circ} \mathrm{C}$ until the fatty acid profiles could be analyzed. Another section of LD meat samples was taken between the 6th to 12th ribs and kept in the chilling room $\left(2-4{ }^{\circ} \mathrm{C}\right)$ for $48 \mathrm{~h}$ before determining meat oxidation. The percentage of intramuscular fat (IMF) of LD determined by Soxhlet instrument using petroleum ether extract [35].

Table 1. Ingredients, chemical compositions and fatty acid profile of total mixed ration (TMR) diets.

\begin{tabular}{|c|c|c|c|c|c|}
\hline \multirow{2}{*}{ Items } & \multicolumn{4}{|c|}{ AER, g/kg DM } & \multirow{2}{*}{ AER } \\
\hline & 0 & 20 & 40 & 60 & \\
\hline \multicolumn{6}{|l|}{ Ingredients (g/kg DM) } \\
\hline Cassava pulp & 300 & 300 & 300 & 300 & \\
\hline King Napier grass silage & 243 & 243 & 243 & 243 & \\
\hline Palm kernel meal & 140 & 140 & 140 & 140 & \\
\hline Cassava chip & 110 & 110 & 110 & 110 & \\
\hline $\begin{array}{l}\text { Dried distillers corn grains } \\
\text { with solubles }\end{array}$ & 80 & 80 & 80 & 80 & \\
\hline Defatted rice bran & 100 & 80 & 60 & 40 & \\
\hline $\begin{array}{l}\text { Anthocyanin extracted residue } \\
\text { (AER) }\end{array}$ & - & 20 & 40 & 60 & \\
\hline Salt & 5 & 5 & 5 & 5 & \\
\hline Sulfur & 2 & 2 & 2 & 2 & \\
\hline Dicalcium phosphate & 5 & 5 & 5 & 5 & \\
\hline Premix & 5 & 5 & 5 & 5 & \\
\hline Urea & 10 & 10 & 10 & 10 & \\
\hline \multicolumn{6}{|l|}{ Chemical compositions } \\
\hline Dry matter ( $\mathrm{g} / \mathrm{kg}$ fresh weight) & 387 & 392 & 395 & 385 & 938 \\
\hline Organic matter (g/kg DM) & 937 & 938 & 939 & 939 & 955 \\
\hline Crude protein (g/kg DM) & 124 & 128 & 123 & 125 & 137 \\
\hline Ether extract (g/kg DM) & 23 & 27 & 33 & 36 & 128 \\
\hline Ash (g/kg DM) & 63 & 62 & 61 & 61 & 55 \\
\hline $\begin{array}{l}\text { Neutral detergent fiber } \\
(\mathrm{g} / \mathrm{kg} \mathrm{DM})\end{array}$ & 43.2 & 43.7 & 42.4 & 42.3 & 32.5 \\
\hline Acid detergent fiber (g/kg DM) & 24.6 & 23.8 & 24.1 & 23.9 & 11.0 \\
\hline Gross energy (MJ/kg DM) & 15.23 & 15.13 & 15.29 & 15.20 & 17.29 \\
\hline Anthocyanin (mg/g DM) & ND & 0.02 & 0.04 & 0.05 & 1.05 \\
\hline $\begin{array}{c}\text { Total phenolic acid (mg gallic } \\
\text { acid/g DM) }\end{array}$ & 2.67 & 2.80 & 3.01 & 3.31 & 8.23 \\
\hline \multicolumn{6}{|l|}{$\begin{array}{c}\text { Fatty acids, } g / 100 \mathrm{~g} \text { of total } \\
\text { fatty acids }\end{array}$} \\
\hline Palmitic C16:0 & 23.58 & 22.95 & 22.58 & 22.51 & 20.42 \\
\hline Palmitoleic C16:1 & 0.16 & 0.12 & 0.17 & 0.17 & 0.20 \\
\hline Stearic C18:0 & 5.10 & 4.85 & 4.58 & 4.25 & 2.72 \\
\hline Oleic C18:1 & 33.94 & 35.07 & 35.71 & 36.61 & 42.01 \\
\hline Linoleic C18:2 n-6 & 30.71 & 30.62 & 30.72 & 30.34 & 29.97 \\
\hline$\alpha$-Linolenic C18:3 n-3 & 3.37 & 2.98 & 2.81 & 2.58 & 0.95 \\
\hline Total saturated fatty acids & 29.96 & 29.2 & 28.57 & 28.20 & 24.6 \\
\hline $\begin{array}{l}\text { Total monounsaturated } \\
\text { fatty acids }\end{array}$ & 35.25 & 36.39 & 37.08 & 38.12 & 43.70 \\
\hline $\begin{array}{l}\text { Total polyunsaturated } \\
\text { fatty acids }\end{array}$ & 34.60 & 34.24 & 34.18 & 33.58 & 31.59 \\
\hline$n-6: n-3$ fatty acid ratio & 9.12 & 10.28 & 10.93 & 11.76 & 31.7 \\
\hline
\end{tabular}




\subsection{Preparation of Meat Sample and Display Conditions}

After chilling, the LD muscle from each carcass was trimmed of external fat and manually cut into piece $1.5 \mathrm{~cm}$ thickness (12 pieces for 3 replication). Samples were then randomly assigned to one of four storage times $(1,3,7$, and 14 days of storage) and placed on moisture absorbent pads in polystyrene trays that were overwrapped with oxygenpermeable polyvinyl chloride (PVC) film. The total number of samples taken from the 16 carcasses for physicochemical analysis was 192 pieces. Samples were stored at $4{ }^{\circ} \mathrm{C}$ in a cooling room under tube light emitting diodes (LED, PEMCO T8 interlight, Shenzhen, China), with a color temperature of $3000 \mathrm{~K}$ and an average lighting intensity of 1.034.2 Lux to simulate the conditions of supermarket display.

\subsection{Color Measurement}

The color of the meat surface was measured at three locations were randomly selected to calculate the average values using a colorimeter CR-400 Chroma Meter (Konica Minolta Holdings Inc., Osaka, Japan) and expressed as CIE (Commission International de I'Eclairage) color coordinates. Lightness $\left(\mathrm{L}^{*}\right)$, redness $\left(\mathrm{a}^{*}\right)$ and yellowness $\left(\mathrm{b}^{*}\right)$ were recorded. Chroma $\left(\mathrm{C}^{*}\right)$ and hue angle $\left(\mathrm{h}^{\circ}\right)$ were calculated from $\mathrm{a}^{*}$ and $\mathrm{b}^{*}$ color coordinates [40] using the following equations:

$$
\begin{aligned}
\mathrm{C}^{*} & =\left(\mathrm{a}^{* 2}+\mathrm{b}^{* 2}\right)^{1 / 2} \\
\mathrm{~h}^{\circ} & =\arctan \left(\mathrm{b}^{*} / \mathrm{a}^{*}\right)
\end{aligned}
$$

For $\mathrm{L}^{*}$, higher values indicated lighter meat; for $\mathrm{a}^{*}$, higher values indicated redder coloring; and for $\mathrm{b}^{*}$, higher values indicated more yellow coloring; higher chroma values indicated more intense red coloring (color saturation); and greater hue angle indicated greater intensity of discoloration.

\subsection{Relative Myoglobin Characteristics}

Myoglobin was extracted from meat samples following the method of Dai et al. [41] with minor modifications. Briefly, $5 \mathrm{~g}$ of meat were mixed with $25 \mathrm{~mL}$ of phosphate buffer (0.04 M, pH 6.8) and homogenized using ACE-11 homogenizer (Nihon seiki, Osaka, Japan) at $9000 \mathrm{rpm}$ for $30 \mathrm{~s}$ in an ice-cold cup and left in the ice bath for $1 \mathrm{~h}$. Then the homogenate was centrifuged at $12,000 \mathrm{rpm}$ at $4{ }^{\circ} \mathrm{C}$ for $25 \mathrm{~min}$. The clear supernatant was filtered with a Whatman no. 42 filter paper (GE Whatman; Sigma Aldrich, St. Louis, MO, USA), and the filtrate was measured using a UV1280-Vis (ultraviolet-visible) spectrophotometer (Shimadzu, Kyoto, Japan) with absorbance at 503, 525, 582, and $557 \mathrm{~nm}$ to calculate myoglobin forms. The proportions form of metmyoglobin (MetMb), oxymyoglobin $(\mathrm{OMb})$, and deoxymyoglobin (DeoMb) were expressed in percentage (\%) using the method of Tang et al. [42] in the following equations:

$$
\begin{gathered}
{[\text { DeoMb }]=\mathrm{CDeoMb} / \mathrm{CMb}=-0.534 \mathrm{R}_{1}+0.594 \mathrm{R}_{2}+0.552 \mathrm{R}_{3}-1.329} \\
{[\mathrm{OxyMb}]=\mathrm{COxyMb} / \mathrm{CMb}=0.722 \mathrm{R}_{1}-1.432 \mathrm{R}_{2}-1.659 \mathrm{R}_{3}+2.599} \\
{[\mathrm{MetMb}]=\mathrm{CMetMb} / \mathrm{CMb}=-0.159 \mathrm{R}_{1}-0.085 \mathrm{R}_{2}+1.262 \mathrm{R}_{3}-0.520}
\end{gathered}
$$

where $R_{1}=A 582 / A 525, R_{2}=A 557 / A 525, R_{3}=A 503 / A 525$.

\subsection{Lipid Peroxidation}

Meat samples were analyzed for lipid peroxidation by measuring levels of 2-thiobarbituric acid reactive substances (TBARS) using the method of Buege and Aust, [43]. Briefly, about $5 \mathrm{~g}$ meat was mixed with $25 \mathrm{~mL}$ of thiobarbituric acid (TBA) stock solution $(0.375 \%$ thiobarbituric acid, $15 \%$ trichloroacetic acid, and $0.25 \mathrm{~N} \mathrm{HCl}$ ) and homogenized using ACE-11 homogenizer (Nihon seiki, Osaka, Japan) at 10,000 rpm for $1 \mathrm{~min}$ in an ice-cold cup. The homogenate was incubated at $100{ }^{\circ} \mathrm{C}$ in a water bath for $20 \mathrm{~min}$, cooled, and centrifuged 
(Labnet Hermle C0326-K, Wehingen, Germany) at 12,000 rpm for $20 \mathrm{~min}$ at $4{ }^{\circ} \mathrm{C}$. The clear supernatant was collected and measured for absorbance at $532 \mathrm{~nm}$ using UV spectrophotometer (T80+UV / Vis, PG Instruments Ltd., Leicestershire, UK) by running a blank containing TBA stock solution. The TBARS value was expressed as milligrams of malonaldehyde per kilogram of meat sample (mg MDA/kg) by calculated using a molar extinction coefficient $\left(156,000 \mathrm{M}^{-1} \cdot \mathrm{cm}^{-1}\right)$ [40] using the following equation:

TBARS number $(\mathrm{mg}$ MDA $/ \mathrm{kg})=$ sample A532 $\times[(1 \mathrm{M}$ TBA chromagen $) / 156,000] \times[(1 \mathrm{~mol} / \mathrm{L} / \mathrm{M}] \times(0.030 \mathrm{~L} / 5 \mathrm{~g}$ meat $) \times(72.07 \mathrm{~g} \mathrm{MDA} / \mathrm{mol} \mathrm{MDA}) \times 1000 \mathrm{mg} / \mathrm{g}) \times 1000 \mathrm{~g} / \mathrm{kg})$

\subsection{Protein Oxidation}

Protein oxidation in the myofibrillar proteins of the meat samples was evaluated based on the protein carbonyl content using 2,4-dinitrophenylhydrazine (DNPH) as described by Levine et al. [44] with some modifications. Briefly, $3 \mathrm{~g}$ of meat were added to $30 \mathrm{~mL}$ of phosphate buffer pH $6.5(20 \mathrm{mM}$, containing $0.6 \mathrm{M} \mathrm{NaCl})$ and homogenized using ACE-11 homogenizer (Nihon seiki, Osaka, Japan) at 10,000 rpm for $30 \mathrm{~s}$ in an ice-cold cup, and four aliquots of $200 \mu \mathrm{L}$ of homogenate were distributed in Eppendorf tubes. All aliquots were mixed with $1 \mathrm{~mL}$ of ice-cold 10\% trichloroacetic acid (TCA) for $15 \mathrm{~min}$ in ice-baths to precipitate the proteins. The tube samples were centrifuged at $6000 \mathrm{rpm}$ for $10 \mathrm{~min}$ at $4{ }^{\circ} \mathrm{C}$ to discard the clear supernatant. TCA $(10 \%)$ was added $(1 \mathrm{~mL})$ to the pellets and the procedures described above were repeated. After removing the supernatant, $500 \mu \mathrm{L}$ of $10 \mathrm{mM}$ DNPH (dissolved in $2.0 \mathrm{M} \mathrm{HCl}$ ) were added to the pellets of two aliquots and $500 \mu \mathrm{L}$ of $\mathrm{HCl}(2.0 \mathrm{M})$ without $\mathrm{DNPH}$ were added to the pellet of two aliquots for blank. All samples were mixed and left in the dark for $1 \mathrm{~h}$, vortexed every 10 min to be derivative. Subsequently, $500 \mu \mathrm{L}$ of TCA $20 \%$ was added to all samples, which were then vortexed, placed in ice baths for $15 \mathrm{~min}$ and centrifuged at $8000 \mathrm{rpm}$ for $10 \mathrm{~min}$ in $4^{\circ} \mathrm{C}$. The resulting supernatant was discarded. To remove excess DNPH, protein pellets were washed three times with $1 \mathrm{~mL}$ of ethanol: ethylacetate $(1: 1, v / v)$, vortexed and centrifuged at $8000 \mathrm{rpm}$ for $10 \mathrm{~min}$ in $4{ }^{\circ} \mathrm{C}$. After each wash, the supernatant was discarded. After the final wash, the samples were left under the hood for $20 \mathrm{~min}$ to remove the excess solvent, and the pellets were subsequently dissolved in $1.5 \mathrm{~mL}$ of guanidine hydrochloride $(6.0 \mathrm{M})$ in $20 \mathrm{mM}$ phosphate buffer ( $\mathrm{pH}$ 6.5) and placed in the dark for $30 \mathrm{~min}$ and vortexed every $10 \mathrm{~min}$. Finally, the sample solution was centrifuged at $12,000 \mathrm{rpm}$ for $10 \mathrm{~min}$ at $4{ }^{\circ} \mathrm{C}$ to remove insoluble material. The carbonyl concentration in the samples was measured using spectrophotometry with absorbance at $370 \mathrm{~nm}$ and $280 \mathrm{~nm}$ using a UV1280-Vis Spectrophotometer (Shimadzu, Kyoto, Japan). The concentration of protein carbonyl was expressed as nmol carbonyl per $\mathrm{mg}$ protein (nmol/mg protein) and calculated using the following equation [44]:

$$
\begin{array}{r}
\mathrm{C}_{\text {hydrazone }} / \mathrm{C}_{\text {protein }}=\left[\mathrm{A}_{370} / \varepsilon_{\text {hydrazone } 370} \times\left(\mathrm{A}_{280}-\mathrm{A}_{370} \times 0.43\right)\right] \times 10^{6}[\mathrm{nmol} / \mathrm{mg} \text { protein }] \\
\text { where } \varepsilon_{\text {hydrazone, } 370} \text { is } 22,000 \mathrm{M}^{-1} \mathrm{~cm}^{-1} \text { and } 0.43=\varepsilon_{\text {hydrazone, } 280} / \varepsilon_{\text {hydrazone, } 370 .} .
\end{array}
$$

\subsection{Meat Fatty Acid Profile}

Fatty acid analysis was performed using the one-step extraction and transmethylation process described by Ruiz-López et al. [39] with some modifications. Briefly, LD samples were trimmed off connective tissue and external fat before blending. Triplicated $0.1 \mathrm{~g}$ of blended muscle samples were extracted and transmethylated with $4 \mathrm{~mL}$ of a mixture containing $\mathrm{H}_{2} \mathrm{SO}_{4}$ : methanol: toluene: 2,2-dimethoxypropane (1.2: 24: 6: 3 by volume) and $500 \mu \mathrm{L}$ of heptane for $2 \mathrm{~h}$ of incubation at $80{ }^{\circ} \mathrm{C}$. After cooling, $200 \mu \mathrm{L}$ of $0.9 \% \mathrm{NaCl}$ was added to the samples and they were vortex-mixed for $3 \mathrm{~min}$, then centrifuged at $3500 \mathrm{rpm}$ for $3 \mathrm{~min}$. The heptane layer in the upper phase of the $200 \mu \mathrm{L}$ that contained the fatty acid methyl esters (FAME) was transferred to a vial bottle $(1.5 \mathrm{~mL})$ and mixed with $400 \mu \mathrm{L}$ of heptane for dilution and immediate analysis. Qualitative measurements FAME content were performed by gas chromatography using an Agilent Technologies 
7890B Gas Chromatograph (GC) System (Agilent Technologies, Santa Clara, CA, USA) with fused silica capillary columns $(30 \mathrm{~m} \times 0.25 \mathrm{~mm}$, film thickness $0.25 \mu \mathrm{m}$; StabilwaxMS, Bellefonte, PA, USA). The injector and detector temperatures were set at $240{ }^{\circ} \mathrm{C}$ and $250{ }^{\circ} \mathrm{C}$, respectively. The GC temperature program was as follows: the initially temperature was $170{ }^{\circ} \mathrm{C}$, held for $2.5 \mathrm{~min} ; 10^{\circ} \mathrm{C} / \mathrm{min}$ until $180{ }^{\circ} \mathrm{C}$, held for $4.5 \mathrm{~min} ; 10{ }^{\circ} \mathrm{C} / \mathrm{min}$ until $210{ }^{\circ} \mathrm{C}$, held for $4 \mathrm{~min} ; 10^{\circ} \mathrm{C} / \mathrm{min}$ until $230{ }^{\circ} \mathrm{C}$, held for $6 \mathrm{~min}$. The total run time was $23 \mathrm{~min}$. The injector was set at $0.5 \mu \mathrm{L}$ of the sample with a split 5:1. Helium was used as a carrier gas with a flow rate of $3 \mathrm{~mL} / \mathrm{min}$. The Food Industry FAME Mix 35077 (RESTEK, Bellefonte, PA, USA) was used as an external standard to identified FAME. Fatty acids were expressed as a percentage of total fatty acids that be calculated as follows: total saturated fatty acids (SFA) = myristic acid $(\mathrm{C} 14: 0)+$ pentadecylic acid (C15:0) + palmitic acid (C16:0) + margaric acid (C17:0) + stearic acid (C18:0) + arachidic acid (C20:0) + behenic acid (C22:0); total monounsaturated fatty acids (MUFA) = palmitoleic acid (C16:1) + heptadecenoic acid (C17:1) + Oleic acid (C18:1) + gondoic acid (C20:1); total polyunsaturated fatty acids (PUFA) $\mathrm{n}-6=$ linoleic acid (C18:2) + dihomo- $\gamma$-linolenic acid (C20:3) + arachidonic acid (C20:4); total PUFA $\mathrm{n}-3=\alpha$-Linolenic acid (C18:3) + eicosapentaenoic acid (C20:5) + docosahexaenoic acid (C22:6); total polyunsaturated fatty acids (PUFA) $=n-6+n-3$. The indices of saturation index (SI) was estimated according to Ulbricht and Southgate, [45] and enzyme activities of $\Delta 9$-desaturase for C16 fatty acids and C18 fatty acids were estimated according to Malau-Aduli et al. [46]:

$$
\begin{gathered}
\Delta 9-\text { desaturase } 16=100 \times[(\mathrm{C} 16: 1 \text { cis9 }) /(\mathrm{C} 16:(1 \text { cis9 })+\mathrm{C} 16: 0)] \\
\Delta 9-\text { desaturase } 18=100 \times[(\mathrm{C} 18: 1 \text { cis9 }) /(\mathrm{C} 18:(1 \text { cis9 })+\mathrm{C} 18: 0)] \\
\text { SI }=(\mathrm{C} 14: 0+\mathrm{C} 16: 0+\mathrm{C} 18: 0) / \Sigma \mathrm{MUFA}+\mathrm{PUFA}
\end{gathered}
$$

\subsection{Statistical Analysis}

The experimental design of meat oxidation was a split-plot with a completely randomized design (CRD). Dietary treatment was the whole plot and storage time was the split-plot. Within the subplot, the meat was assigned to 1, 3, 7, or 14 days of storage. The repeated option in PROC MIXED was used to assess covariance-variance structure among the repeated measures for displaying color data. The most appropriate structure was determined using Akaike and Bayesian information criterion output. Type-3 fixed effects of treatments diet, storage time, and their interactions were analyzed using the mixed procedure of statistical analysis system [47]. The random terms included animal replication, animal replication*treatments diet (error A), and unspecified residual error B. Least squares means for protected F tests $(p<0.05)$ were separated using the probability of difference (pdiff) option and were considered significant at $p<0.05$. For fatty acid profiles was analyzed through analysis of variance (ANOVA) using the generalized linear model (GLM). Orthogonal polynomials were evaluated to determine linear and quadratic responses to supplementation of AER, with the level of significance at $p<0.05$.

\section{Results}

The average total phenolic acid and anthocyanin content in AER were $8.23 \mathrm{mg}$ of gallic acid/g and $1.05 \mathrm{mg}$ of cyanidin-3-O-glucoside equivalents/g by dry weight, respectively. Anthocyanin and total phenolic acid content increased with increased levels of AER in the diet treatments, while anthocyanins were not detected in the control sample $(0 \mathrm{~g} / \mathrm{kg}$ AER). The main fatty acids included in the treatment diets and AER were C16:0, C18:1, and C18:2. However, C16:0, C18:0, C18:3, and total PUFA decreased with higher levels of AER in the diet.

\subsection{Color Parameter}

The effects of AER supplementation on the color of LD during storage time are presented in Table 2. Dietary treatment and storage time did not have any impact on 
lightness $\left(L^{*}, p=0.66\right)$. All meat samples showed similar $L^{*}$ on the first day as they did at the end of the storage time. Yellowness $\left(b^{*}\right)$ was affected by storage time $(p<0.0001)$ and dietary treatment $(p=0.02)$. Values for $b^{*}$ decreased in the sample for all treatments as storage time increased. However, samples from the $60 \mathrm{~g} / \mathrm{kg}$ AER group were the most stable and showed the lowest $b^{*}$ value from day 1 to day 7 of storage.

Table 2. Color of Longissimus dorsi (LD) from male dairy cattle with AER in TMR diets at different storage time.

\begin{tabular}{|c|c|c|c|c|c|}
\hline \multirow{2}{*}{ Color } & \multirow{2}{*}{ AER, g/kg } & \multicolumn{4}{|c|}{ Storage Time (Day) } \\
\hline & & 1 & 3 & 7 & 14 \\
\hline \multirow{4}{*}{$\begin{array}{c}L^{*} \\
S E=2.141\end{array}$} & 0 & 41.15 & 40.71 & 40.34 & 41.32 \\
\hline & 20 & 40.25 & 39.65 & 39.82 & 38.92 \\
\hline & 40 & 41.11 & 42.22 & 39.83 & 38.49 \\
\hline & 60 & 38.19 & 38.52 & 37.95 & 38.76 \\
\hline \multirow{4}{*}{$\begin{array}{c}\mathrm{a}^{*} \\
\mathrm{SE}=0.899\end{array}$} & 0 & $22.07^{\mathrm{A}, \mathrm{a}}$ & $21.05^{a}$ & $16.04^{\mathrm{B}, \mathrm{b}}$ & $14.59^{\mathrm{B}, \mathrm{c}}$ \\
\hline & 20 & $22.83^{\mathrm{A}, \mathrm{a}}$ & $21.67^{\mathrm{a}, \mathrm{b}}$ & $20.65^{\mathrm{A}, \mathrm{b}}$ & $17.62^{\mathrm{A}, \mathrm{c}}$ \\
\hline & 40 & $22.35^{\mathrm{A}, \mathrm{a}}$ & $21.50^{\mathrm{a}}$ & $19.82^{\mathrm{A}, \mathrm{b}}$ & $16.31^{\mathrm{A}, \mathrm{c}}$ \\
\hline & 60 & $20.14^{\mathrm{B}, \mathrm{a}}$ & $19.11^{\mathrm{a}}$ & $18.56^{\mathrm{A}, \mathrm{a}}$ & $17.78^{\mathrm{A}, \mathrm{b}}$ \\
\hline \multirow{4}{*}{$\begin{array}{c}b^{*} \\
S E=0.743\end{array}$} & 0 & $9.68^{\mathrm{A}, \mathrm{a}}$ & $9.18^{\mathrm{A}, \mathrm{a}}$ & $8.17^{\mathrm{A}, \mathrm{a}, \mathrm{b}}$ & $6.64^{\mathrm{b}}$ \\
\hline & 20 & $9.67^{\mathrm{A}, \mathrm{a}}$ & $8.97^{\mathrm{A}, \mathrm{a}}$ & $8.37^{\mathrm{A}, \mathrm{a}}$ & $5.7^{\mathrm{b}}$ \\
\hline & 40 & $8.88^{\mathrm{A}, \mathrm{a}}$ & $9.57 \mathrm{~A}, \mathrm{a}$ & $7.55^{\mathrm{A}, \mathrm{a}}$ & $5.68^{b}$ \\
\hline & 60 & $6.69^{\mathrm{B}}$ & $6.48^{\mathrm{B}}$ & $6.11^{\mathrm{B}}$ & 6.45 \\
\hline \multirow{4}{*}{$\begin{array}{c}\text { Chroma } \\
\mathrm{SE}=1.216\end{array}$} & 0 & $24.12^{\mathrm{A}, \mathrm{a}}$ & $22.98^{\mathrm{A}, \mathrm{a}}$ & $19.04^{\mathrm{B}, \mathrm{b}}$ & $17.24^{b}$ \\
\hline & 20 & $24.81^{\mathrm{A}, \mathrm{a}}$ & $23.49^{\mathrm{A}, \mathrm{a}}$ & $22.31^{\mathrm{A}, \mathrm{b}}$ & $18.55^{c}$ \\
\hline & 40 & $24.1^{\mathrm{A}, \mathrm{a}}$ & $23.58^{\mathrm{A}, \mathrm{a}}$ & $21.27^{\mathrm{B}, \mathrm{b}}$ & $17.36^{c}$ \\
\hline & 60 & $21.24^{\text {B }}$ & $20.22^{B}$ & $19.61^{\mathrm{B}}$ & 18.99 \\
\hline \multirow{4}{*}{$\begin{array}{l}\text { Hue angle } \\
\mathrm{SE}=2.408\end{array}$} & 0 & $23.71^{\mathrm{A}}$ & $23.48^{\mathrm{A}}$ & $26.81^{\mathrm{A}}$ & $24.48^{\mathrm{A}}$ \\
\hline & 20 & $22.86^{\mathrm{A}, \mathrm{a}}$ & $22.25^{\mathrm{A}, \mathrm{a}}$ & $21.9^{\mathrm{B}, \mathrm{a}}$ & $17.48^{\mathrm{B}, \mathrm{b}}$ \\
\hline & 40 & $21.44^{\mathrm{A}}$ & $23.76^{\mathrm{A}}$ & $20.56^{\mathrm{B}}$ & $19.03^{\mathrm{B}}$ \\
\hline & 60 & $18.02^{\mathrm{B}}$ & $18.34^{\mathrm{B}}$ & $17.65^{\text {B }}$ & $19.6^{\mathrm{B}}$ \\
\hline
\end{tabular}

$\overline{\mathrm{A}-\mathrm{C}}$ Least square means with different letters within the same day of storage time were significantly different $(p<0.05) ;{ }^{\mathrm{a}-\mathrm{b}}$ Least square means with different letters within the same treatments were significantly different $(p<0.05)$; L*: lightness; $\mathrm{a}^{*}$ : redness; $\mathrm{b}^{*}$ : yellowness; SE: standard errors; AER: anthocyanin extracted residue; LD: longissimus dorsi; TMR: total mixed ration.

There was highly significant interaction between dietary treatment and storage time for $\mathrm{a}^{*}(p=0.0007)$ and chroma $(p=0.0472)$. The $\mathrm{a}^{*}$ value for meat samples from all treatment conditions decreased significantly $(p<0.05)$ during 14 days of storage. There was a significant effect on meat samples from the $60 \mathrm{~g} / \mathrm{kg}$ AER supplementation group. This group showed the lowest $a^{*}$ value on day 1 , whereas on day 7 and day 14 , control samples $(0 \mathrm{~g} / \mathrm{kg}$ AER $)$ had significantly lower $\mathrm{a}^{*}(p<0.05)$ than did samples from all other AER treatment groups.

Chroma values for meat samples from cattle fed $0 \mathrm{~g} / \mathrm{kg}$ AER decreased significantly $(p<0.05)$ during 14 days of storage. Meat samples from cattle supplemented with $60 \mathrm{~g} / \mathrm{kg}$ AER showed a significant effect on day 1 and day 3, with the lowest chroma values. However, such significant differences were no longer evident on day 7 and day 14 . Hue angle was also affected by dietary treatment $(p=0.07)$. Meat from cattle with $60 \mathrm{~g} / \mathrm{kg}$ AER in their diet had the lowest hue angle on day 1 and day 3 , and the control samples had the highest hue angle on days 7 and 14 . 


\subsection{Relative Myoglobin Characteristics}

The effects of AER in the diet on myoglobin redox formation in meat samples during storage time are presented in Table 3. The deoxymyoglobin content of samples from all treatments steadily decreased $(p<0.0001)$ over time. Oxymyoglobin content was lowest for control samples and decreased significantly $(p=0.0022)$ with increased storage time. However, levels of oxymyoglobin in meat samples from cattle supplemented with 20 to $60 \mathrm{~g} / \mathrm{kg}$ AER did not significantly during storage time.

Table 3. Proportions of oxymyoglobin $(\mathrm{OMb})$, deoxymyoglobin $(\mathrm{DMb})$, and metmyoglobin $(\mathrm{MMb})$ of LD from male dairy cattle with AER in TMR diets at different storage times.

\begin{tabular}{|c|c|c|c|c|c|}
\hline \multirow{2}{*}{ Parameter } & \multirow{2}{*}{$\begin{array}{l}\text { AER, } \\
\text { g/kg }\end{array}$} & \multicolumn{4}{|c|}{ Storage Time (Day) } \\
\hline & & 1 & 3 & 7 & 14 \\
\hline \multirow{4}{*}{$\begin{array}{c}\% \mathrm{DMb} \\
\mathrm{SE}=2.268\end{array}$} & 0 & $36.77^{\mathrm{a}}$ & $31.78^{b}$ & $28.38^{b, c}$ & $23.85^{c}$ \\
\hline & 20 & $35.23^{a}$ & $28.93^{b}$ & $28.10^{b}$ & $23.39^{c}$ \\
\hline & 40 & $35.01^{\mathrm{a}}$ & $33.84^{a, b}$ & $29.40^{b}$ & $23.88^{c}$ \\
\hline & 60 & $38.78^{a}$ & $30.78^{b}$ & $30.40^{b}$ & $24.48^{c}$ \\
\hline \multirow{4}{*}{$\begin{array}{c}\% \mathrm{OMb} \\
\mathrm{SE}=3.699\end{array}$} & 0 & $53.18^{a}$ & $53.62^{a}$ & $42.96^{\mathrm{B}, \mathrm{b}}$ & $42.12^{\mathrm{B}, \mathrm{b}}$ \\
\hline & 20 & 54.56 & 53.31 & $51.23^{\mathrm{A}}$ & $50.49^{\mathrm{A}}$ \\
\hline & 40 & 52.91 & 50.66 & $47.53^{\mathrm{A}, \mathrm{B}}$ & $47.71^{\mathrm{A}, \mathrm{B}}$ \\
\hline & 60 & 53.36 & 52.85 & $48.42^{\mathrm{A}, \mathrm{B}}$ & $46.60^{\mathrm{A}, \mathrm{B}}$ \\
\hline \multirow{4}{*}{$\begin{array}{c}\% \mathrm{MMb} \\
\mathrm{SE}=2.121\end{array}$} & 0 & $10.93^{d}$ & $15.59^{c}$ & $29.59 \mathrm{~A}, \mathrm{~b}$ & $34.74^{\mathrm{A}, \mathrm{a}}$ \\
\hline & 20 & $11.24^{\mathrm{d}}$ & $18.81^{\mathrm{c}}$ & $21.69^{B, b}$ & $27.02^{\mathrm{B}, \mathrm{a}}$ \\
\hline & 40 & $12.97^{\mathrm{d}}$ & $16.47^{\mathrm{c}}$ & $24.08^{B, b}$ & $29.21^{B, a}$ \\
\hline & 60 & $9.41^{\mathrm{d}}$ & $17.38^{\mathrm{c}}$ & $22.13^{\mathrm{B}, \mathrm{b}}$ & $29.97^{B, a}$ \\
\hline
\end{tabular}

$\overline{\mathrm{A}-\mathrm{B}}$ Least square means with different letters within the same day of storage time were significantly different $(p<0.05){ }^{\text {a-d }}$ Least square means with different letters within the same treatments were significantly different $(p<0.05)$; SE: standard errors; AER: anthocyanin extracted residue; LD: Longissimus dorsi; TMR: total mixed ration.

There was significant interaction $(p=0.0018)$ between dietary treatment and storage time for metmyoglobin levels. Metmyoglobin in meat from all of AER treatment groups increased significantly $(p<0.05)$ during 14 days of storage time. For day 1 and day 3 , metmyoglobin was not significantly different among treatments. However, for day 7 and day 14 , metmyoglobin in the control samples was significantly $(p<0.05)$ higher than in samples for the other treatments.

\subsection{Lipid Peroxidation}

The least square means and standard error for TBARS values for the meat samples during storage time are presented in Figure 1. There was significant interaction $(p=0.0002)$ between dietary treatment and storage time for TBARS values. TBARS values for meat samples from all AER treatments increased significantly $(p<0.05)$ during 14 days of storage. The TBARS values for meat samples from cattle fed diets with 20 to $60 \mathrm{~g} / \mathrm{kg}$ AER were lower than for the control group on day 3 and day 7 of storage. Meat samples from cattle fed diets with $60 \mathrm{~g} / \mathrm{kg}$ AER had the lowest TBARS value on day 14 of storage compared with other treatments. 


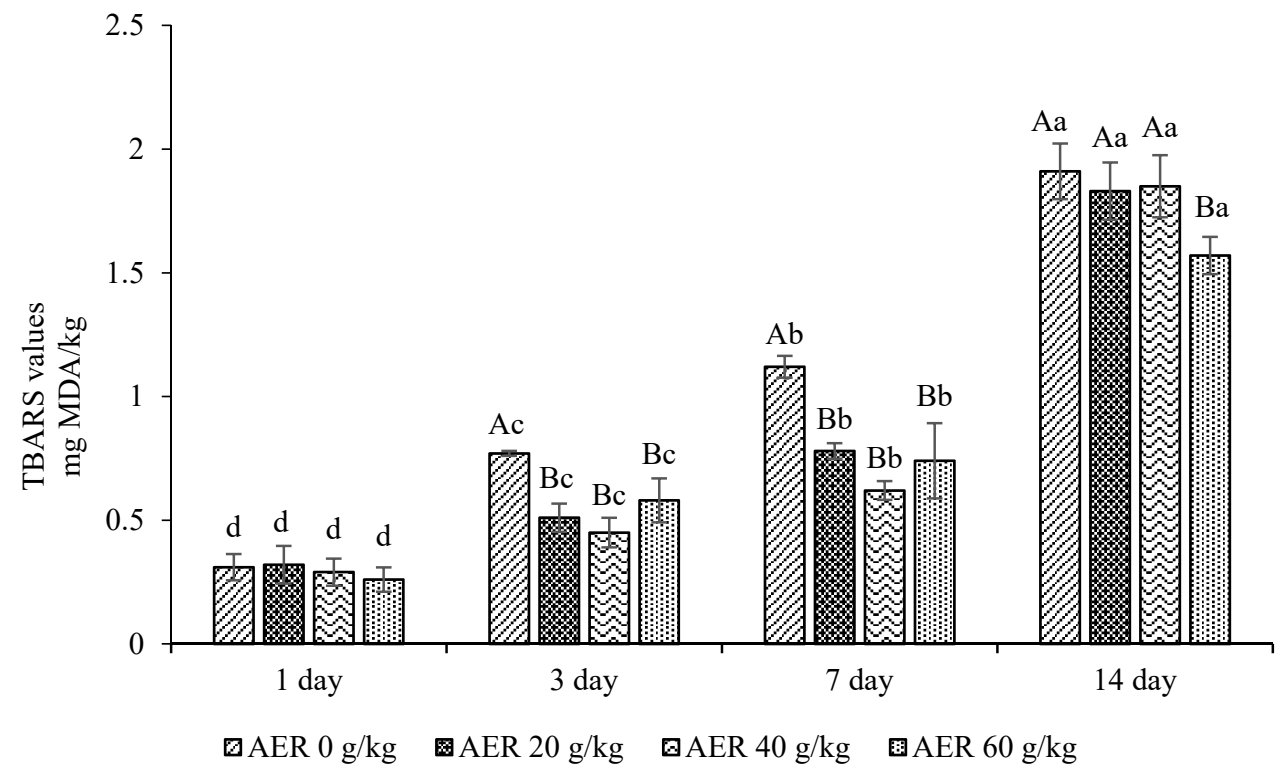

Figure 1. Thiobarbituric acid reactive substances (TBARS) values (mg malonaldehyde (MDA)/ $\mathrm{kg}$ ) of LD from male dairy cattle with AER in TMR diet at different storage time. ${ }^{A-B}$ Least square means with different letters within the same day of storage time were significantly different $(p<0.05) ;{ }^{\text {a-d }}$ Least square means with different letters within the same treatments were significantly different $(p<0.05)$; AER: anthocyanin extracted residue; LD: Longissimus dorsi; TMR: total mixed ration.

\subsection{Protein Oxidation}

The least square means and standard error for protein carbonyl values for meat samples during storage time are presented in Figure 2. There was no significant interaction between dietary treatment and storage time for protein carbonyl. However, protein carbonyl was significantly affected by dietary treatment and storage time. Protein carbonyl values increased with increased storage time for all meat samples, whereas samples from the AER dietary treatment groups showed significantly lower protein carbonyl values on day 7 and day 14 .

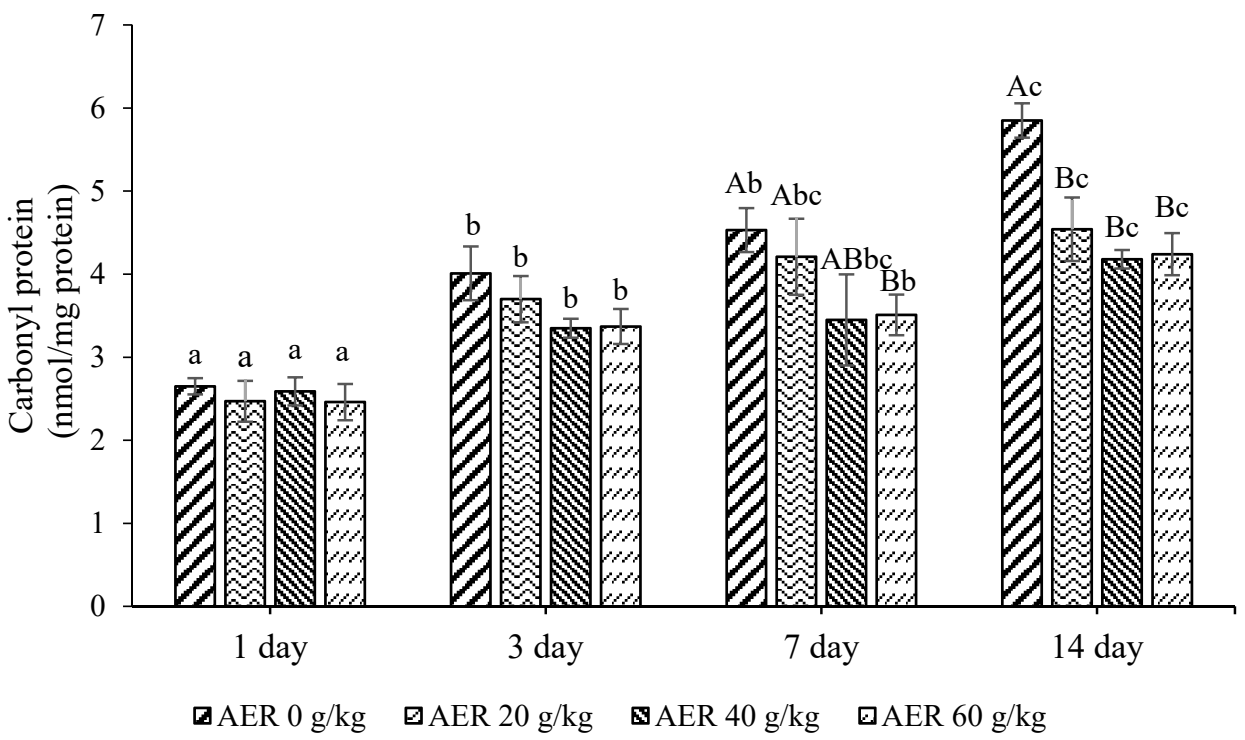

Figure 2. Protein carbonyl of LD from male dairy cattle with AER in TMR diet at different storage time. ${ }^{\text {A-B }}$ Least square means with different letters within the same day of storage time are significantly different $(p<0.05) ;{ }^{\mathrm{a}-\mathrm{c}}$ Least square means with different letters within the same treatments are significantly different $(p<0.05)$; AER: anthocyanin extracted residue; LD: Longissimus dorsi; TMR: total mixed ration. 


\subsection{Fatty Acid Composition}

The effects of AER in the diet on the fatty acid composition of the $\mathrm{LD}(\mathrm{g} / 100 \mathrm{~g}$ of total fatty) are presented in Table 4 . The main saturated fatty acids were C16:0 (20.80-24.13\%) and C18:0 (16.18-16.88\%). Other medium chain fatty acid (C14:0, C15:0, C17:0) accounted for approximately $3 \%$ of total fatty acids. The amount of saturated fatty acids (C14:0, C15:0, $\mathrm{C} 16: 0, \mathrm{C} 17: 0, \mathrm{C} 18: 0, \mathrm{C} 20: 0)$ and total saturated fatty acid content were not significantly different among treatments. Increased levels of AER in the diet were associated with a linear increase in C22:0; however, the increase was not great enough to reach a statistical significance $(p=0.06)$. The total monounsaturated fatty acid content accounted for 33-39\% of the total detected fatty acid content detected.

Table 4. Fatty acid (FA) composition (\% of all fatty acids analyzed) of the lipids in LD of male dairy cattle with AER in TMR diets.

\begin{tabular}{|c|c|c|c|c|c|c|c|}
\hline \multirow{2}{*}{$\begin{array}{l}\text { Fatty Acids, g/100 g } \\
\text { of Total Fatty Acids }\end{array}$} & \multicolumn{4}{|c|}{ AER Supplemented, g/kg } & \multirow{2}{*}{ SEM } & \multicolumn{2}{|c|}{ Contrast } \\
\hline & 0 & 20 & 40 & 60 & & $\mathbf{L}$ & $\mathbf{Q}$ \\
\hline \multicolumn{8}{|c|}{ Saturated FA (SFA) } \\
\hline C14:0 & 2.88 & 2.28 & 3.36 & 2.47 & 0.370 & 0.92 & 0.71 \\
\hline C15:0 & 0.05 & 0.14 & 0.15 & 0.11 & 0.055 & 0.44 & 0.24 \\
\hline C16:0 & 23.50 & 22.48 & 24.13 & 20.80 & 0.844 & 0.11 & 0.19 \\
\hline C17:0 & 0.52 & 0.53 & 0.50 & 0.48 & 0.045 & 0.47 & 0.72 \\
\hline C18:0 & 16.18 & 16.88 & 16.48 & 16.81 & 1.080 & 0.76 & 0.86 \\
\hline C20:0 & 0.18 & 0.21 & 0.17 & 0.27 & 0.048 & 0.31 & 0.45 \\
\hline C22:0 & 0.19 & 0.21 & 0.21 & 0.30 & 0.038 & 0.06 & 0.37 \\
\hline Other SFA & 0.49 & 0.59 & 0.49 & 0.60 & 0.101 & 0.58 & 0.95 \\
\hline Total SFA & 43.99 & 42.79 & 45.49 & 41.14 & 1.595 & 0.42 & 0.34 \\
\hline \multicolumn{8}{|c|}{ Monounsaturated FA (MUFA) } \\
\hline C16:1 cis-9 & 3.13 & 2.28 & 2.75 & 2.03 & 0.339 & 0.08 & 0.87 \\
\hline C17:1 cis-10 & 0.81 & 0.82 & 0.65 & 0.84 & 0.076 & 0.81 & 0.24 \\
\hline C18:1 cis-9 & 34.26 & 30.91 & 29.89 & 29.31 & 1.615 & 0.05 & 0.41 \\
\hline C20:1 cis- 11 & 0.20 & 0.20 & 0.21 & 0.21 & 0.036 & 0.88 & 0.94 \\
\hline Other MUFA & 1.05 & 0.83 & 1.05 & 0.89 & 0.222 & 0.79 & 0.91 \\
\hline Total MUFA & 39.44 & 35.04 & 34.56 & 33.27 & 2.144 & 0.06 & 0.46 \\
\hline \multicolumn{8}{|c|}{ Polyunsaturated FA (PUFA) } \\
\hline C18:2 n-6 & 8.50 & 11.85 & 11.09 & 13.82 & 0.861 & $<0.01$ & 0.72 \\
\hline C18:3 n-3 & 0.42 & 0.60 & 0.56 & 0.72 & 0.040 & $<0.01$ & 0.63 \\
\hline C20:3 n-6 & 1.32 & 1.71 & 1.71 & 1.89 & 0.145 & 0.05 & 0.74 \\
\hline C20:4 n-6 & 5.21 & 6.59 & 5.88 & 7.68 & 0.566 & 0.01 & 0.69 \\
\hline C20:5 n-3 (EPA) & 0.21 & 0.34 & 0.31 & 0.38 & 0.035 & 0.01 & 0.49 \\
\hline C22:6 n-3 (DHA) & 0.30 & 0.32 & 0.30 & 0.39 & 0.033 & 0.19 & 0.29 \\
\hline Other PUFA & 0.60 & 0.66 & 0.38 & 0.69 & 0.172 & 0.99 & 0.23 \\
\hline Total PUFA & 16.57 & 22.17 & 19.95 & 25.59 & 1.522 & $<0.01$ & 0.98 \\
\hline Total PUFA n-3 & 0.94 & 1.26 & 1.18 & 1.50 & 0.091 & $<0.01$ & 0.96 \\
\hline Total PUFA n-6 & 15.03 & 20.15 & 18.39 & 23.41 & 1.455 & $<0.01$ & 0.97 \\
\hline Total UFA & 56.01 & 57.21 & 54.51 & 58.86 & 1.549 & 0.29 & 0.2 \\
\hline UFA/SFA & 1.27 & 1.33 & 1.21 & 1.43 & 0.078 & 0.34 & 0.33 \\
\hline PUFA/SFA ratio & 0.37 & 0.50 & 0.43 & 0.61 & 0.040 & $<0.01$ & 0.60 \\
\hline MUFA/SFA ratio & 0.90 & 0.83 & 0.77 & 0.81 & 0.067 & 0.28 & 0.41 \\
\hline$n-6 / n-3$ ratio & 15.96 & 16.09 & 15.64 & 15.56 & 0.804 & 0.71 & 0.94 \\
\hline Saturation index (SI) & 0.45 & 0.45 & 0.50 & 0.43 & 0.033 & 0.98 & 0.28 \\
\hline D9-desaturase 16 & 11.66 & 9.39 & 10.24 & 9.13 & 1.171 & 0.22 & 0.63 \\
\hline D9-desaturase 18 & 68.00 & 64.50 & 64.35 & 63.61 & 2.531 & 0.26 & 0.63 \\
\hline IMF content $(\%)$ & 5.36 & 4.85 & 5.83 & 4.03 & 0.650 & 0.32 & 0.34 \\
\hline
\end{tabular}

EPA: eicosapentaenoic acid; DHA: docosahexaenoic acid; SEM: standard error of means; L: linear; Q: quadratic; AER: anthocyanin extracted residue; LD: Longissimus dorsi; TMR: total mixed ration; IMF: intramuscular fat.

The major monounsaturated fatty acid in all treatments was C18:1, accounting for 29-34\%. Feeding AER treatments did not significantly differ in monounsaturated fatty acids (C16:1, C17:1, C20:1); on the other hand, C18:1 $(p=0.05)$ and total monounsaturated 
fatty acids $(p=0.06)$ were slightly decreased when the level of AER increased but not reach a statistical difference.

For all treatments, the total polyunsaturated fatty acid content accounted for $16-25 \%$ of the total detected fatty acid content. C18:2 (8.50-13.82\%) and C20:4 (5.21-7.68\%) were the most abundant polyunsaturated fatty acids in the LD samples. Polyunsaturated fatty acid content (C18:2, C18:3, C20:3, C20:4, C20:5) was increased linearly and significantly $(p<0.05)$ with increased levels of AER in the diet.

The total amounts of polyunsaturated fatty acids, total polyunsaturated fatty acids $\mathrm{n}-3$, total polyunsaturated fatty acids $\mathrm{n}-6$, and the PUFA/SFA ratio increased significantly $(p<0.05)$ and linearly with increased AER in the diet. However, total unsaturated, UFA/SFA, MUFA/SFA ratio, n-6/n-3 ratio, saturation index (SI), D9-desaturase 16 and D9-desaturase 18 were similar for all diets.

\section{Discussion}

\subsection{Effect of Anthocyanin-Extracted Residue (AER) in the Diet on Meat Color}

The amount of AER in the diet had an influence on meat redness ( $\left.\mathrm{a}^{*}\right)$, yellowness $\left(b^{*}\right)$, chroma and hue angle of LD samples until 14 days of storage. These results were consistent with those of the study by de Oliveira Monteschio et al. [18], who explained that the addition of clove and rosemary essential oils, other natural antioxidants, to the diet reduced meat oxidation would cause differences in color.

In addition, the current results indicated that LD samples obtained from cattle fed higher amounts AER had lower values for $\mathrm{a}^{*}, \mathrm{~b}^{*}$, chroma, and hue, and less intense and vivid color than the control samples at day 1 of storage. Similarly, Jaturasitha et al. [48] reported that feeding purple rice to fatten pigs resulted in lower $a^{*}$ values compared with feeding them white rice. In addition, Jerónimo et al. [49] reported that lamb fed $6 \%$ vegetable oil in diets had lower a* values due to high PUFA content in the meat, which was susceptible to high myoglobin oxidation.

The current results showed that on day 3 of storage, $a^{*}$ values for meat from cattle fed AER was not significantly different compared with those of the control group; however, at days 7 and 14, a* values were higher, indicating that myoglobin oxidation was lower in meat from cattle fed AER after 3 days in storage. The reduction in a* values from day 1 to day 14 storage was due to the stage of oxymyoglobin to metmyoglobin and the lipid peroxidation interaction in meat discoloration, leading to increased brown coloring in the meat, which is associated with spoiled and old meat [50]. In agreement with Cardoso et al. [51], these results indicate that meat quality was altered by diet because $\mathrm{a}^{*}$ values indicated delayed color deterioration during storage. Antioxidants had the effect of stabilizing the muscle membranes, leading to improvement in meat color [52].

Changes in meat color ( $\mathrm{a}^{*}$ and $\mathrm{b}^{*}$ values) over time in this experiment were due to oxidation of red oxymyoglobin into metmyoglobin, which causes brown coloring in meat [53]. However, meat from cattle fed higher percentages of AER in their diets showed less color deterioration and lower metmyoglobin formation, possibly because of the antioxidant effect of reduction in oxidation. Several studies have reported that anthocyanins as a natural source of antioxidants inhibited both lipid and protein oxidation and stabilized the red coloring in the meat during refrigerated storage $[53,54]$.

\subsection{Effect of AER in the Diet on Meat Oxidation}

The sensitivity of meat to oxidation can vary by animal species and breed and muscle type assessed, as well as by the diet provided to the animals. This study found that the lipid peroxidation (TBARS) and protein oxidation (protein carbonyl) at days 3 to 14 of storage in cattle fed diets supplemented with AER were lower than in cattle fed without AER. This difference was associated with high dietary contents of anthocyanins and phenolic compounds, which may improve the oxidative stability of meat over time. However, over feeding antioxidant supplements to animals may cause pro-oxidant effects and increase oxidation [55]. 
The effect of antioxidant supplementation in the diet was consistent with effects observed in previous studies [48,52], whereby black rice was fed to pigs and it was reported that TBARS content in raw meat reduced over time in storage. Chikwanha et al. [56] reported a reduction in lipid and protein oxidation of raw meat when grape pomace was added to the diet of lambs. de Oliveira Monteschio et al. [18] demonstrated that supplementation of natural substances in the diets of feedlot-finished heifers decreased lipid peroxidation in raw meat during aging. TBARS values in this study ranged from 1.57 to $1.91 \mathrm{mg}$ MDA $/ \mathrm{kg}$ on day 14 of storage, which may reflect increased risk of off-flavor development in the meat. According to Campo et al. [57], $2 \mathrm{mg}$ MDA/ $\mathrm{kg}$ of meat could be considered the threshold indicating off-flavor in oxidized beef. An imbalance between antioxidant ability and free radicals in meat may increase the risk of oxidative damage [58]. The metal chelation process and consumption in the chain breaking mechanism probably cause the reduction of antioxidants, resulting in increased levels of oxidation [59]. Several reports confirmed that low oxidation values in the meat corresponded with the high antioxidant activity [25,56,60]. Higher levels of lipid peroxidation and protein carbonyl content may be related to exposure to pro-oxidant factors [61].

Increases in protein carbonyl have been shown to determine protein oxidation in meat. Protein oxidation can have deleterious effects on meat quality such as reduced water-holding capacity [62], altered color [62], texture [63], flavor [64], aroma [65], and nutritional value [62]. The total protein carbonyl content in animal tissue is estimated to be 1-2 nmol/mg protein [65]. However, protein carbonyl increases during aging/chilled storage of meat [62]. The level of protein carbonyls reported in this study was consistent with Rowe et al. [66], who found that chilled storage of beef for 10 days increased protein carbonyl from 3.1 to $5.1 \mathrm{nmol} / \mathrm{mg}$ protein, and Lindahl et al. [67], who reported an increase from 4.8 to $6.9 \mathrm{nmol} / \mathrm{mg}$ protein. However, this study showed that AER supplementation can slow increases in protein carbonyl after day 7 of storage, which supports the findings of Ganhão et al. [68] who found that phenolic-rich fruit extract as an antioxidant source may protect against the formation of protein carbonyl in cooked patties.

\subsection{Effect of AER in the Diet on Fatty Acid Profile}

The ratio of saturated and unsaturated fatty acids in meat samples in this experiment was similar to that of previous research with crossbred bulls fed essential oils [55], with steers fed wet distillers grains plus solubles [69], with bulls fed concentrate and TMR [70], and with steers fed algal residue [71]. However, there were differences in the fatty acid composition of n-3, n-6, PUFA and PUFA/SFA among treatments.

In previous studies, dietary intake of plant-rich anthocyanins increased the $n-3$ and n-6 PUFA proportion in the plasma of humans, fish, and mammalian models such as rats. de Lorgeril et al. [31] reported that proportions of n-3 PUFA in plasma were increased in red wine drinkers because red wines are rich in polyphenols. Villasante et al. [32] found that feeding purple corn extract rich in anthocyanins increased the proportions of total n-3 PUFA in the plasma of rainbow trout. Similarly, Toufektsian et al. [33] revealed that feeding purple corn extract rich in anthocyanins increased the proportion of very longchain (n-3) eicosapentaenoic acid (C20:5, EPA) and docosahexaenoic acid (C22:6, DHA) in the plasma of rats. According to Muíño et al. [72], lamb fed diets supplemented with red wine extract rich in proanthocyanidins increased the proportion of EPA in LD muscle. Furthermore, Jaturasitha et al. [48] reported that feeding purple rice to pigs resulted in a higher proportion of n-3 PUFA in raw loin chops.

This study showed that increased levels of AER in the diet were associated with linear increases in the proportions of n-3 and n-6 PUFA. These results indicate that the bioactive compounds such as anthocyanins and phenolic acid in AER may have direct impacts on the proportions of n-3 and n-6 PUFA in beef. Toufektsian et al. [33] suggested that there are two kinds of EPA and DHA enhancements in the body. Anthocyanins may have an impact on the conversion biosynthesis pathway from their precursor $\alpha$-linolenic acid into EPA and DHA. 
AER contained black rice bran that was high in C18:1. Particularly, the proportions of C18:1 in the diet increased following higher AER inclusion. However, the proportions of C18:1 in the meat linearly decreased with higher levels of AER. A similar result was observed by De Mello et al. [69], who reported that beef from steer fed higher distillers grains had proportions of C18:1 linearly decreased. The reason for this decrease is still unknown. It is possible that the anthocyanin from AER may alter ruminal bacteria's ability in reducing cis n-9 fatty acid, as well as mechanisms of absorption and transportation of these fatty acids from the small intestine to the muscle [73]. The bacteria are largely responsible for biohydrogenation of unsaturated fatty acid in the rumen. Particularly, some bacteria utilized C18:1 as one of the main substrates that is susceptible to rapid hydrogenation, with 18:0 being the end product [70]. Previous studies have reported that increased intake of C18:1 from rice bran oil [74] and distiller dried grains with solubles [75] of steer did not have an effect on C18:1 in meat.

The composition of fatty acids in meat could affect its nutritional value for humans. Consumption of more PUFA than SFA reduces risk factors associated with cardiovascular disease [76]. Thus, the ratio of PUFA/SFA can be used as a measurement of fatty acid composition in food. According to the Annual Report of the National Food Survey Committee (HMSO) [77], a ratio of PUFA/SFA higher than 0.45 is recommended for reducing the risk of cardiovascular disease. High levels of AER in the diet improved the ratio of PUFA/SFA in the treated samples to 0.61 compared with 0.37 for the control samples.

High proportions of n-3 and n- 6 PUFA have been used to qualify the nutritive values of beef. The essential fatty acids n-3 and n-6 PUFA must be obtained from food because they cannot be produced de novo. Higher levels of n-3 PUFA and an n-6/n-3 ratio of 4:1 in food is associated with health benefits and a reduction in risk factors related to cardiovascular disease and cancer [78]. The addition of AER did not increase the $n-6 / n-3$ ratio; however, the ratios for all treatments groups were higher than 4:1 due to a high proportion of linoleic acid (C18:2) from cereals (corn) used in the feed, resulting in high a proportion of linoleic acid in the beef. According to Fruet et al. [79], meat from grain maize-fed animals had higher $n-6 / n-3$ ratios than meat from pasture-fed animals because grains contain high levels of linoleic acid (n-6 fatty acid).

\section{Conclusions}

Feeding diets containing AER affected the quality of meat during storage time. Meat from cattle-fed diets containing AER, showed greater color stability and lower oxidation of lipid, protein and myoglobin than meat from cattle fed diets without AER. These results suggest the conclusion that antioxidants in the feed of cattle improve meat oxidation leading to an extension of the shelf life of meat. Moreover, meat from cattle fed AER had a higher proportion of n-3 PUFA, which may indicate the meat is healthier for consumers; however, more research examining the total amount of n-3 PUFA in meat is also required in order to determine possible beneficial effects.

Author Contributions: Conceptualization, R.P., S.U., J.U. and P.P.; data curation, R.P. and S.U.; methodology, R.P., S.U., P.P., W.T. and J.U.; project administration, R.P. and S.U.; formal analysis, R.P., S.U. and P.P.; investigation, S.U., P.P., J.U., A.C. and R.P.; resources, S.U., P.P., J.U., A.C. and C.N.; writing—original draft preparation, R.P.; writing—review and editing, R.P., S.U. and A.C.; supervision, S.U., J.U., P.P. and C.N.; funding acquisition, S.U., J.U., A.C. and C.N.; All authors have read and agreed to the published version of the manuscript.

Funding: This research was funded by the Thailand Research Fund through the Royal Golden Jubilee Ph.D. Program (Grant No. PHD/0194/2556). The Increased Production Efficiency and Meat Quality of Native Beef and Buffalo Research Group, Khon Kaen University, is acknowledged for some financial support in the feeding trial.

Institutional Review Board Statement: The study was conducted according to the guidelines of the Ethic of Animal Experimentation of National Research Council of Thailand (U1-04090-2559) and approved by the Ethics Committee of Khon Kaen University (AEKKU 77/2556). 
Data Availability Statement: The data presented in this study are available on request from the corresponding author.

Acknowledgments: We would like to thank the Department of Animal Science, Faculty of Agriculture, Khon Kaen University and the Department of Biochemistry, Faculty of Science, Khon Kaen University for the possibility of carrying out the research study.

Conflicts of Interest: The authors declare that they have no conflict of interest associated with this research.

\section{References}

1. OECD: Meat Consumption [Internet]; OECD: Paris, France, 2020; Available online: https://data.oecd.org/agroutput/meat? consumption.htm (accessed on 23 January 2021).

2. FAOSTATE: Beef Production [Internet]; FAOSTATE: Rome, Italy, 2020; Available online: http://www.fao.org/faostat/en/\#data/QL (accessed on 23 January 2021).

3. Bunmee, T.; Chaiwang, N.; Kaewkot, C.; Jaturasitha, S. Current situation and future prospects for beef production in Thailand-A review. Asian-Australas. J. Anim. Sci. 2018, 31, 968-975. [CrossRef] [PubMed]

4. Coleman, L.W.; Hickson, R.E.; Schreurs, N.M.; Martin, N.P.; Kenyon, P.R.; Lopez-Villalobos, N.; Morris, S.T. Carcass characteristics and meat quality of Hereford sired steers born to beef-cross-dairy and Angus breeding cows. Meat Sci. 2016, 121, 403-408. [CrossRef] [PubMed]

5. Butt, M.A.; Bhatti, J.A.; Khalique, A.; Shahid, M.Q. Effect of fat supplementation on physiological and reproductive performance of Holstein Friesian bulls during summer. Trop. Anim. Health Prod. 2019, 51, 2595-2601. [CrossRef] [PubMed]

6. Akbarian, A.; Michiels, J.; Degroote, J.; Majdeddin, M.; Golian, A.; Smet, S. De Association between heat stress and oxidative stress in poultry; mitochondrial dysfunction and dietary interventions with phytochemicals. J. Anim. Sci. Biotechnol. 2016, 7, 1-4. [CrossRef] [PubMed]

7. Domínguez, R.; Gullón, P.; Pateiro, M.; Munekata, P.E.S.; Zhang, W.; Lorenzo, J.M. Tomato as Potential Source of Natural Additives for Meat Industry. A Review. Antioxidants 2020, 9, 73. [CrossRef]

8. Gallo, M.; Ferracane, R.; Naviglio, D. Antioxidant addition to prevent lipid and protein oxidation in chicken meat mixed with supercritical extracts of Echinacea angustifolia. J. Supercrit. Fluids 2012, 72, 198-204. [CrossRef]

9. Domínguez, R.; Pateiro, M.; Gagaoua, M.; Barba, F.J.; Zhang, W.; Lorenzo, J.M. A comprehensive review on lipid oxidation in meat and meat products. Antioxidants 2019, 8, 429. [CrossRef]

10. Alfaia, C.M.M.; Alves, S.P.; Lopes, A.F.; Fernandes, M.J.E.; Costa, A.S.H.; Fontes, C.M.G.A.; Castro, M.L.F.; Bessa, R.J.B.; Prates, J.A.M. Effect of cooking methods on fatty acids, conjugated isomers of linoleic acid and nutritional quality of beef intramuscular fat. Meat Sci. 2010, 84, 769-777. [CrossRef]

11. Faustman, C.; Cassens, R.G. The effect of cattle breed and muscle type on discoloration and various biochemical parameters in fresh beef. J. Anim. Sci. 1991, 69, 184. [CrossRef]

12. de Zawadzki, A.; Arrivetti, L.O.R.; Vidal, M.P.; Catai, J.R.; Nassu, R.T.; Tullio, R.R.; Berndt, A.; Oliveira, C.R.; Ferreira, A.G.; Neves-Junior, L.F.; et al. Mate extract as feed additive for improvement of beef quality. Food Res. Int. 2017, 99, 336-347. [CrossRef]

13. Lorenzo, J.M.; Pateiro, M.; Domínguez, R.; Barba, F.J.; Putnik, P.; Kovačević, D.B.; Shpigelman, A.; Granato, D.; Franco, D. Berries extracts as natural antioxidants in meat products: A review. Food Res. Int. 2018, 106, 1095-1104. [CrossRef] [PubMed]

14. Giannenas, I.; Bonos, E.; Filliousis, G.; Stylianaki, I.; Kumar, P.; Lazari, D.; Christaki, E.; Florou-Paneri, P. Effect of a polyherbal or an arsenic-containing feed additive on growth performance of broiler chickens, intestinal microbiota, intestinal morphology, and lipid oxidation of breast and thigh meat. J. Appl. Poult. Res. 2019, 28, 164-175. [CrossRef]

15. Wang, T.; Li, J.; Shao, Y.; Yao, W.; Xia, J.; He, Q.; Huang, F. The effect of dietary garcinol supplementation on oxidative stability, muscle postmortem glycolysis and meat quality in pigs. Meat Sci. 2020, 161, 107998. [CrossRef] [PubMed]

16. de Evan, T.; Cabezas, A.; de la Fuente Vázquez, J.; Carro, M.D. Feeding agro-Industrial By-Products to Light Lambs: Influence on Meat Characteristics, Lipid Oxidation, and Fatty Acid Profile. Animals 2020, 10, 1572. [CrossRef] [PubMed]

17. Qwele, K.; Hugo, A.; Oyedemi, S.O.; Moyo, B.; Masika, P.J.; Muchenje, V. Chemical composition, fatty acid content and antioxidant potential of meat from goats supplemented with Moringa (Moringa oleifera) leaves, sunflower cake and grass hay. Meat Sci. 2013, 93, 455-462. [CrossRef] [PubMed]

18. de Oliveira Monteschio, J.; de Souza, K.A.; Vital, A.C.P.; Guerrero, A.; Valero, M.V.; Kempinski, E.M.B.C.; Barcelos, V.C.; Nascimento, K.F.; do Prado, I.N. Clove and rosemary essential oils and encapsuled active principles (eugenol, thymol and vanillin blend) on meat quality of feedlot-finished heifers. Meat Sci. 2017, 130, 50-57. [CrossRef]

19. Gerber, P.J.; Uwizeye, A.; Schulte, R.P.O.; Opio, C.I.; de Boer, I.J.M. Nutrient use efficiency: A valuable approach to benchmark the sustainability of nutrient use in global livestock production? Curr. Opin. Environ. Sustain. 2014, 9, 122-130. [CrossRef]

20. Salami, S.A.; Luciano, G.; O'Grady, M.N.; Biondi, L.; Newbold, C.J.; Kerry, J.P.; Priolo, A. Sustainability of feeding plant by-products: A review of the implications for ruminant meat production. Anim. Feed Sci. Technol. 2019, 251, 37-55. [CrossRef]

21. Kapcum, C.; Uriyapongson, J. Effects of storage conditions on phytochemical and stability of purple corn cob extract powder. Food Sci. Technol. 2018, 38, 301-305. [CrossRef] 
22. Pang, Y.; Ahmed, S.; Xu, Y.; Beta, T.; Zhu, Z.; Shao, Y.; Bao, J. Bound phenolic compounds and antioxidant properties of whole grain and bran of white, red and black rice. Food Chem. 2018, 240, 212-221. [CrossRef]

23. Bendokas, V.; Stanys, V.; Mažeikienè, I.; Trumbeckaite, S.; Baniene, R.; Liobikas, J. Anthocyanins: From the Field to the Antioxidants in the Body. Antioxidants 2020, 9, 819. [CrossRef] [PubMed]

24. Rey, A.; Amazan, D.; Cordero, G.; Olivares, A.; López-Bote, C.J. Lower oral doses of micellized $\alpha$-tocopherol compared to $\alpha$-tocopheryl acetate in feed modify fatty acid profiles and improve oxidative status in pigs. Int. J. Vitam. Nutr. Res. 2014, 84, 229-243. [CrossRef] [PubMed]

25. Prommachart, R.; Belem, T.S.; Uriyapongson, S.; Rayas-Duarte, P.; Uriyapongson, J.; Ramanathan, R. The effect of black rice water extract on surface color, lipid oxidation, microbial growth, and antioxidant activity of beef patties during chilled storage. Meat Sci. 2020, 164, 108091. [CrossRef] [PubMed]

26. Purba, N.S.; Uriyapongson, S.; Uriyapongson, J. Effect of purple corn cob extract powder and black rice bran oil on quality and shelf life of fresh beef. Songklanakarin J. Sci. Technol. 2020, 42, 645-651.

27. Park, S.Y.; Lee, J.W.; Kim, G.W.; Kim, H.Y. Effect of black rice powder on the quality properties of pork patties. Korean J. Food Sci. Anim. Resour. 2017, 37, 71-78. [CrossRef] [PubMed]

28. Loypimai, P.; Moongngarm, A.; Naksawat, S. Application of natural colorant from black rice bran for fermented Thai pork sausage-Sai Krok Isan. Int Food Res. J. 2017, 24, 1529-1537.

29. Kirisattayakul, W.; Wattanathorn, J.; Iamsaard, S.; Jittiwat, J.; Suriharn, B.; Lertrat, K. Neuroprotective and Memory-Enhancing Effect of the Combined Extract of Purple Waxy Corn Cob and Pandan in Ovariectomized Rats. Oxid. Med. Cell. Longev. 2017, 2017, 1-12. [CrossRef]

30. Morakotsriwan, N.; Wattanathorn, J.; Kirisattayakul, W.; Chaisiwamongkol, K. Autistic-like behaviors, oxidative stress status, and histopathological changes in cerebellum of valproic acid rat model of autism are improved by the combined extract of purple rice and silkworm pupae. Oxid. Med. Cell. Longev. 2016, 2016, 1-10. [CrossRef]

31. de Lorgeril, M.; Salen, P.; Martin, J.-L.; Boucher, F.; de Leiris, J. Interactions of wine drinking with omega-3 fatty acids in patients with coronary heart disease: A fish-like effect of moderate wine drinking. Am. Heart J. 2008, 155, 175-181. [CrossRef]

32. Villasante, A.; Patro, B.; Chew, B.; Becerra, M.; Wacyk, J.; Overturf, K.; Powell, M.S.; Hardy, R.W. Dietary intake of purple corn extract reduces fat body content and improves antioxidant capacity and n-3 polyunsaturated fatty acid profile in plasma of rainbow trout, Oncorhynchus mykiss. J. World Aquac. Soc. 2015, 46, 381-394. [CrossRef]

33. Toufektsian, M.-C.; Salen, P.; Laporte, F.; Tonelli, C.; de Lorgeril, M. Dietary flavonoids increase plasma very long-chain (n-3) fatty acids in rats. J. Nutr. 2011, 141, 37-41. [CrossRef] [PubMed]

34. NRC. Nutrient Requirement of Dairy Cattle, 7th revised ed.; National Research Council National Academy Press: Washington, DC, USA, 2001.

35. AOAC. Official Methods of Analysis, 16th ed.; Association of Official Analytical Chemists: Washington, DC, USA, 1995.

36. Van Soest, P.J.; Robertson, J.B.; Lewis, B.A. Methods for dietary fiber, neutral detergent fiber, and nonstarch polysaccharides in relation to animal nutrition. J. Dairy Sci. 1991, 74, 3583-3597. [CrossRef]

37. Lee, J.; Durst, R.W.; Wrolstad, R.E. Determination of total monomeric anthocyanin pigment content of fruit juices, beverages, natural colorants, and wines by the $\mathrm{pH}$ differential method: Collaborative study. AOAC Int. 2005, 88, 1269-1278. [CrossRef]

38. Ainsworth, E.A.; Gillespie, K.M. Estimation of total phenolic content and other oxidation substrates in plant tissues using Folin-Ciocalteu reagent. Nat. Protoc. 2007, 2, 875-877. [CrossRef] [PubMed]

39. Ruiz-López, N.; Martínez-Force, E.; Garcés, R. Sequential one-step extraction and analysis of triacylglycerols and fatty acids in plant tissues. Anal. Biochem. 2003, 317, 247-254. [CrossRef]

40. AMSA. Guidelines for Meat Color Evaluation; American Meat Science Association: Chicago, IL, USA, 2012.

41. Dai, Y.; Miao, J.; Yuan, S.Z.; Liu, Y.; Li, X.M.; Dai, R.T. Colour and sarcoplasmic protein evaluation of pork following water bath and ohmic cooking. Meat Sci. 2013, 93, 898-905. [CrossRef]

42. Tang, J.; Faustman, C.; Hoagland, T.A. Krzywicki Revisited: Equations for Spectrophotometric Determination of Myoglobin Redox Forms in Aqueous Meat Extracts. J. Food Sci. 2006, 69, 717-720. [CrossRef]

43. Buege, J.A.; Aust, S.D. Microsomal lipid peroxidation. Methods Enzymol. 1978, 52, 302-310.

44. Levine, R.L.; Williams, J.A.; Stadtman, E.P.; Shacter, E. [37] Carbonyl assays for determination of oxidatively modified proteins. Methods Enzymol. 1994, 233, 346-357.

45. Ulbricht, T.L.V.; Southgate, D.A.T. Coronary heart disease: Seven dietary factors. Lancet 1991, 338, 985-992. [CrossRef]

46. Malau-Aduli, A.E.O.; Siebert, B.D.; Bottema, C.D.K.; Pitchford, W.S. A comparison of the fatty acid composition of triacylglycerols in adipose tissue from Limousin and Jersey cattle. Aust. J. Agric. Res. 1997, 48, 715-722. [CrossRef]

47. SAS. User's Guide: Statistic, Version 6, 12th ed.; SAS Institute Inc.: Cary, NC, USA, 1998.

48. Jaturasitha, S.; Ratanapradit, P.; Piawong, W.; Kreuzer, M. Effects of feeding purple rice (Oryza sativa L. Var. Glutinosa) on the quality of pork and pork products. Asian-Australas. J. Anim. Sci. 2016, 29, 555-563. [CrossRef] [PubMed]

49. Jerónimo, E.; Alfaia, C.M.M.; Alves, S.P.; Dentinho, M.T.P.; Prates, J.A.M.; Vasta, V.; Santos-Silva, J.; Bessa, R.J.B. Effect of dietary grape seed extract and Cistus ladanifer L. in combination with vegetable oil supplementation on lamb meat quality. Meat Sci. 2012, 92, 841-847. [CrossRef] [PubMed]

50. Faustman, C.; Suman, S.P. The Eating Quality of Meat: I-Color. Lawrie's Meat Sci. 2017, 329-356. 
51. Cardoso, G.P.; Dutra, M.P.; Fontes, P.R.; Ramos, A.D.; de Miranda Gomide, L.A.; Ramos, E.M. Selection of a chitosan gelatin-based edible coating for color preservation of beef in retail display. Meat Sci. 2016, 114, 85-94. [CrossRef]

52. Kil, D.Y.; Ryu, S.N.; Piao, L.G.; Kong, C.S.; Han, S.J.; Kim, Y.Y. Effect of feeding cyanidin 3-glucoside (c3g) high black rice bran on nutrient digestibility, blood measurements, growth performance and pork quality of pigs. Asian-Australas. J. Anim. Sci. 2006, 19, 1790-1798. [CrossRef]

53. Nowak, A.; Czyzowska, A.; Efenberger, M.; Krala, L. Polyphenolic extracts of cherry (Prunus cerasus L.) and blackcurrant (Ribes nigrum L.) leaves as natural preservatives in meat products. Food Microbiol. 2016, 59, 142-149. [CrossRef]

54. Turgut, S.S.; Işıkçı, F.; Soyer, A. Antioxidant activity of pomegranate peel extract on lipid and protein oxidation in beef meatballs during frozen storage. Meat Sci. 2017, 129, 111-119. [CrossRef]

55. Rivaroli, D.C.; Guerrero, A.; Velandia Valero, M.; Zawadzki, F.; Eiras, C.E.; del Campo, M.M.; Sañudo, C.; Mendes Jorge, A.; Nunes do Prado, I. Effect of essential oils on meat and fat qualities of crossbred young bulls finished in feedlots. Meat Sci. 2016, 121, 278-284. [CrossRef]

56. Chikwanha, O.C.; Muchenje, V.; Nolte, J.E.; Dugan, M.E.R.; Mapiye, C. Grape pomace (Vitis vinifera L. cv. Pinotage) supplementation in lamb diets: Effects on growth performance, carcass and meat quality. Meat Sci. 2019, 147, 6-12. [CrossRef]

57. Campo, M.M.; Nute, G.R.; Hughes, S.I.; Enser, M.; Wood, J.D.; Richardson, R.I. Flavour perception of oxidation in beef. Meat Sci. 2006, 72, 303-311. [CrossRef] [PubMed]

58. Shah, M.A.; Bosco, S.J.D.; Mir, S.A. Plant extracts as natural antioxidants in meat and meat products. Meat Sci. 2014, 98, 21-33. [CrossRef] [PubMed]

59. Carocho, M.; Morales, P.; Ferreira, I.C.F.R. Antioxidants: Reviewing the chemistry, food applications, legislation and role as preservatives. Trends Food Sci. Technol. 2018, 71, 107-120. [CrossRef]

60. de Oliveira Ferreira, N.S.; Rosset, M.; Lima, G.; Stuelp Campelo, P.M.; de Macedo, R.E.F. Effect of adding Brosimum gaudichaudii and Pyrostegia venusta hydroalcoholic extracts on the oxidative stability of beef burgers. LWT 2019, 108, 145-152. [CrossRef]

61. Cunha, L.C.M.; Monteiro, M.L.G.; Lorenzo, J.M.; Munekata, P.E.S.; Muchenje, V.; de Carvalho, F.A.L.; Conte-Junior, C.A. Natural antioxidants in processing and storage stability of sheep and goat meat products. Food Res. Int. 2018, 111, 379-390. [CrossRef] [PubMed]

62. Estévez, M. Protein carbonyls in meat systems: A review. Meat Sci. 2011, 89, 259-279. [CrossRef]

63. Malheiros, J.M.; Braga, C.P.; Grove, R.A.; Ribeiro, F.A.; Calkins, C.R.; Adamec, J.; Chardulo, L.A.L. Influence of oxidative damage to proteins on meat tenderness using a proteomics approach. Meat Sci. 2019, 148, 64-71. [CrossRef]

64. Toldra', F. Proteolysis and lipolysis in flavour development of dry-cured meat products. Meat Sci. 1998, 49, 101-110. [CrossRef]

65. Requena, J.R.; Chao, C.-C.; Levine, R.L.; Stadtman, E.R. Glutamic and aminoadipic semialdehydes are the main carbonyl products of metal-catalyzed oxidation of proteins. Proc. Natl. Acad. Sci. USA 2001, 98, 69-74. [CrossRef]

66. Rowe, L.J.; Maddock, K.R.; Lonergan, S.M.; Huff-Lonergan, E. Influence of early postmortem protein oxidation on beef quality1. J. Anim. Sci. 2004, 82, 785-793. [CrossRef]

67. Lindahl, G.; Lagerstedt, Å.; Ertbjerg, P.; Sampels, S.; Lundström, K. Ageing of large cuts of beef loin in vacuum or high oxygen modified atmosphere-Effect on shear force, calpain activity, desmin degradation and protein oxidation. Meat Sci. 2010, 85, 160-166. [CrossRef] [PubMed]

68. Ganhão, R.; Estévez, M.; Kylli, P.; Heinonen, M.; Morcuende, D. Characterization of selected wild mediterranean fruits and comparative efficacy as inhibitors of oxidative reactions in emulsified raw pork burger patties. J. Agric. Food Chem. 2010, 58, 8854-8861. [CrossRef] [PubMed]

69. de Mello, A.S.; Jenschke, B.E.; Senaratne, L.S.; Carr, T.P.; Erickson, G.E.; Calkins, C.R. Effects of finishing diets containing wet distillers grains plus solubles on beef quality attributes and fatty acid profile. Meat Sci. 2018, 136, 16-22. [CrossRef] [PubMed]

70. Horcada, A.; Polvillo, O.; Juárez, M.; Avilés, C.; Martínez, A.L.; Peña, F. Influence of feeding system (concentrate and total mixed ration) on fatty acid profiles of beef from three lean cattle breeds. J. Food Compos. Anal. 2016, 49, 110-116. [CrossRef]

71. Morrill, J.C.; Sawyer, J.E.; Smith, S.B.; Miller, R.K.; Johnson, M.D.; Wickersham, T.A. Post-extraction algal residue in beef steer finishing diets: II. Beef flavor, fatty acid composition, and tenderness. Algal Res. 2017, 25, 578-583. [CrossRef]

72. Muíño, I.; Apeleo, E.; de la Fuente, J.; Pérez-Santaescolástica, C.; Rivas-Cañedo, A.; Pérez, C.; Díaz, M.T.; Cañeque, V.; Lauzurica, S. Effect of dietary supplementation with red wine extract or vitamin E, in combination with linseed and fish oil, on lamb meat quality. Meat Sci. 2014, 98, 116-123. [CrossRef]

73. Gill, R.K.; Vanoverbeke, D.L.; Depenbusch, B.; Drouillard, J.S.; Dicostanzo, A. Impact of beef cattle diets containing corn or sorghum distillers grains on beef color, fatty acid profiles, and sensory attributes. J. Anim. Sci. 2008, 86, 923-935. [CrossRef]

74. Mirattanaphra, M.; Suksombat, W. Effect of rumen-protected rice bran oil on carcass quality and fatty acid profile of beef from crossbred Wagyu steers. Songklanakarin J. Sci. Technol. 2020, 42, 123-131.

75. Lancaster, P.A.; Corners, J.B.; Thompson, L.N.; Fritsche, K.L.; Williams, J.E. Distiller's Dried Grains with Solubles Affects Fatty Acid Composition of Beef. Prof. Anim. Sci. 2007, 23, 715-720. [CrossRef]

76. Wood, J.; Richardson, R.; Nute, G.; Fisher, A.; Campo, M.; Kasapidou, E.; Sheard, P.; Enser, M. Effects of fatty acids on meat quality: A review. Meat Sci. 2004, 66, 21-32. [CrossRef]

77. HMSO. Nutritional Aspects of Cardiovascular Disease. Report on Health and Social Subjects. no. 46; HMSO, Department of Health: London, UK, 1994. 
78. Simopoulos, A.P. Omega-6/Omega-3 Essential Fatty Acid Ratio and Chronic Diseases. Food Rev. Int. 2004, 20, 77-90. [CrossRef]

79. Fruet, A.P.B.; Stefanello, F.S.; Rosado Júnior, A.G.; de Souza, A.N.M.; Tonetto, C.J.; Nörnberg, J.L. Whole grains in the finishing of culled ewes in pasture or feedlot: Performance, carcass characteristics and meat quality. Meat Sci. 2016, 113, 97-103. [CrossRef] [PubMed] 